\title{
Historical wealth accounts for Britain: progress and puzzles in measuring the sustainability of economic growth. ${ }^{1}$
}

Eoin McLaughlin, Nick Hanley, David Greasley, Jan Kunnas, Les Oxley and Paul Warde

\begin{abstract}
Estimates of Britain's Comprehensive Wealth are reported for the period 1760-2000. They include measures of produced, natural and human capital, and illustrate the changing composition of Britain's assets over this time period. We show how Genuine Savings, GS (a year-on-year measure of the change in total capital and a claimed indicator of sustainable development) has evolved over time. Changes in total wealth are compared to alternative, investment-based measures of GS, including variants augmented with the value of exogenous technology. Additionally, the possible effects of population change on wealth, and the implications of including $\mathrm{CO}_{2}$ emissions in natural capital are considered.
\end{abstract}

Keywords: Comprehensive Wealth, Genuine Savings, Sustainability, British Economic History JEL: Q01, Q32, Q56, N13, N14

This version: November $28^{\text {th }} 2013$.

\footnotetext{
${ }^{1}$ We thank the Leverhulme Trust for funding this research under the project "History and the Future". We also thank Kirk Hamilton, David Maddison and an anonymous referee for comments on an earlier version of this paper.
} 


\section{Introduction.}

How to define and measure sustainable development are questions which have interested economists for over three decades. Sustainable development of an economy has been defined by per capita utility not declining over time, or by an economy's total stock of capital being maintained in value terms (Neumayer, 2010). The economy's total capital stock comprises the sum of produced, natural, human and social capital stocks (World Bank, 2006; Hanley, Shogren and White, 2006). Arrow et al (2012) relate sustainability to comprehensive wealth, which they argue depends on the value of "...the entire range of capital assets to which people have access...reproducible capital goods (roads, buildings), human capital, natural capital, population, public knowledge and institutions". Within natural capital, one can identify non-renewable resources such as oil and coal reserves, but also the asset value of ecosystems which depend in turn on the flow of ecosystem services over time (Barbier, 2011). Arrow et al (2012) also treat time itself as a capital asset, representing exogenous shifts in an economy's production possibilities. Sustainability is then measured by and depends on how society manages its comprehensive wealth: increases in comprehensive wealth translate into increases in inter-generational well-being.

Here we show how British comprehensive wealth (total capital) and its constituents have changed over the period 1760-2000, a period which spans an industrial revolution during which significant changes occurred in the structure of the economy, its technology, its population and their standards of living. Examining changes in different components of the aggregate capital stock (human, produced, and natural) is of interest since economic development can be seen as a process whereby a country re-arranges and augments its capital stock, perhaps running down an initial stock of natural capital, and accumulating stocks of human and produced capital. We go on to calculate year-on-year changes in total wealth (a measure known as genuine savings, or comprehensive investment), highlighting the puzzles that emerge from the alternative measures.

In the weak sustainability model (Neumayer, 2010), a sufficient degree of substitutability is assumed between the different elements of a nation's total capital or comprehensive wealth so that no particular constraint needs to be placed on the time path of any particular element of the overall capital stock. This assumption has proved controversial, particularly the implication that natural capital can be run down without limit, so long as "enough" of the rents from natural capital extraction are re-invested in other forms of capital, when valued at correct shadow prices - the Hartwick Rule (Hartwick, 1977; d'Autume and Schubert, 2008). Given the assumption of weak sustainability, a macro level test of sustainable development is then to examine whether, year-on-year, an economy's overall capital stock is falling, rising, or remaining constant. Beginning with Pearce and Atkinson (1993), the genuine savings ${ }^{2}$ emerged as a measure of changes in this overall capital stock (Hamilton and Clemens, 1999, Pezzey, 2004). Genuine savings (GS) sums the value of year-

\footnotetext{
${ }^{2}$ Also refered to as Adjusted Net Savings or Comprehensive Investment.
} 
on-year changes in each individual element of the capital stock of a country, valuing these changes using shadow prices which reflect the marginal contribution of each stock to welfare, defined as the present value of aggregated utility over time. Changes in the stock of certain pollutants (such as $\mathrm{CO}_{2}$ ) are sometimes added to the index (for example in the World Bank estimates), valued using their marginal damage costs. Changes in human capital can be approximated using expenditures on education, or a measure based on discounted lifetime earnings by skill level (Arrow et al, 2012; Le et al, 2006; Escosura and Roses, 2010). The effects of technological change, resource price appreciation (capital gains/losses) and population change can also be incorporated into the GS indicator (Pezzey et al, 2006).

The intuition of Pearce and Atkinson (1993) was that countries with positive levels of GS would satisfy a requirement of weak sustainability, since by implication their aggregate capital stocks would not be declining in value. In contrast, countries with negative GS values would be experiencing un-sustainable development. Whilst the theoretical underpinnings of GS are well-established (if much debated), empirical tests of the extent to which a positive GS in a particular year is a good indicator of improving (or at least of non-declining) wellbeing over time remain very limited (Ferreira, Hamilton and Vincent, 2008). Greasley et al (2013) use the data reported in the present paper to test the relationship over the period 1760-2000 between British GS and future well-being, and find that higher values for GS are associated with the present value of changes in future consumption and real wages up to 100 years ahead.

In the following Section 2 we outline how each component of comprehensive wealth or total capital which we were able to consider is calculated for Britain ${ }^{3}$. Section 3 reports alternative, investment-based, estimates of GS and section 4 explores some puzzles in wealth accounting and in measuring changes in comprehensive wealth. Section 5 explains how carbon dioxide emissions could be included in these calculations, whilst Section 6 shows how population growth might dilute comprehensive wealth. Finally, section 7 contains a concluding discussion.

\section{Calculating the Wealth of Britain, 1760-2000.}

This section outlines the data and methodology used in compiling stocks of British wealth, including reproducible, natural and human capital from 1760-2000, and presents our findings. These data, when reported as the changes in wealth also provide one measure of GS, which is compared to estimates of GS based on direct measures of investment in section 4. Please refer to the "Data Appendix" for full details on historical sources used.

\footnotetext{
${ }^{3}$ In the paper "Britain" refers to the United Kingdom less the island of Ireland.
} 


\subsection{Total wealth}

A top-down estimate of total (or comprehensive) wealth facilitates identifying the shares of each form of measured capital within total wealth, and the estimation of social capital as a residual, sometimes labelled as intangible wealth. This residual will also include some of the value of other missing assets if they are reflected in public and private consumption flows. We adopt the World Bank $(2006,2011)$ methodology and estimate total wealth in year $t$ as the present value of consumption (private and government) flows over $(t+25)$ years ${ }^{4}$. That is, for each year in the data, total wealth is the discounted value of consumption looking 25 years forwards. From 1987 to 2000 we use the World Bank methodology of calculating wealth which treats consumption as an annuity. Aggregate consumption is discounted by 2.5\%/year, which equates to the average interest on British government long bonds 17652000 less retail price inflation, as reported by Officer and Williamson (2013). Both wealth and wealth per capita are presented in Figure 1. All values have been deflated to the 2000 price level using a GDP deflator. As can be seen, both total wealth and wealth per capita rose over the period.

\section{Figure 1: Total wealth and wealth per capita, $1760-2000$}



\footnotetext{
${ }^{4}$ Pre-1870 consumption has been estimated as GDP minus investment.
} 


\subsection{Reproducible capital}

Both gross and net historical reproducible capital stock estimates are available. Since our timeframe incorporates periods of substantial structural and technological change, we utilize measures of the net produced capital, taken from Feinstein and Pollard (1988), Feinstein (1972) and Kamps (2006), see Figure 2.

Figure 2: Net reproducible capital stock, 1760-2000

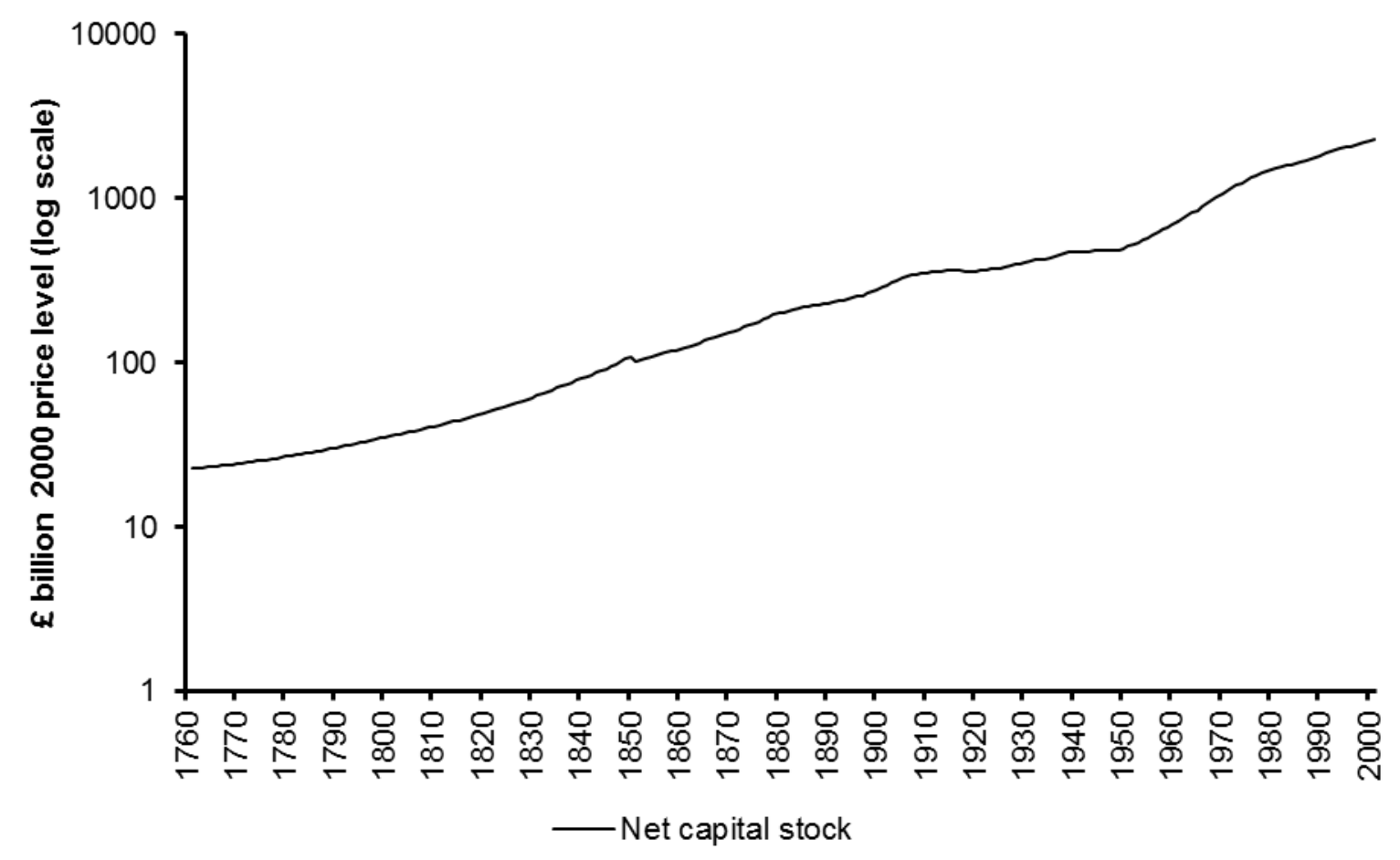

\subsection{Natural Capital}

Natural capital is measured as consisting of non-renewable resources such as coal and iron ore; renewable resources such as forests; and the value of agricultural land. This omits some types of natural capital, for example the non-market value flows from ecosystems. There are essentially two ways of valuing natural capital, which we comment on in section 4 . The World Bank methodology values the sum of discounted income streams (rents) from exploiting a country's stock of, for example, oil, over a discrete time period which is related to a measure of resource lifetimes. The net present values of natural capital have been calculated as the discounted rents looking 25 years forwards in time from the year of calculation. For the years 1760-1970, we thus take the discounted values of rents (price minus cost multiplied by production) in each year over a 25 -year time horizon. That is, for the 1800 estimate, we add up discounted rents from 1800 to 1825 . For all years from 1985 onwards, we project forwards future rents so that we always sum up discounted returns over 25 years. ${ }^{5}$ The implication for non-renewable resources is that, irrespective of the physical size of a reserve (e.g. of coal) which may last for centuries at present rates of

\footnotetext{
${ }^{5}$ We assume that future rents grow by the average growth rate of real prices from 1970-2000.
} 
consumption, its asset value relates to the possibility of an economy to effectively utilise it to generate value.

An alternative approach by Muñoz et al (2012) places a monetary value on the measured stock of natural capital reserves in any year, which assumes that all of a reserve is exploited in the year of accounting. This emphasises the physical scale of the reserves and is much more susceptible to changes in the rate of discovery or depletion.

\subsubsection{Forestry}

The measures of forest stocks combine estimates of the volume of timber $\left(\mathrm{m}^{3}\right)$ per hectare and the forest area, Figure 3. Forestry rents are calculated by multiplying the annual change in the standing volume of timber by timber prices per $\mathrm{m}^{3}$ less the cost of labour; we then calculate the present value of these annual rents which include positive and negative changes in the standing volume (see the Data Appendix for sources). Muñoz et al measures of the stock are derived by estimating the standing volume of timber multiplied by the price-cost of timber, both estimates are presented in Figure 4.

\section{Figure 3: Standing volume of timber and change in standing volume of} timber, 1750--2000

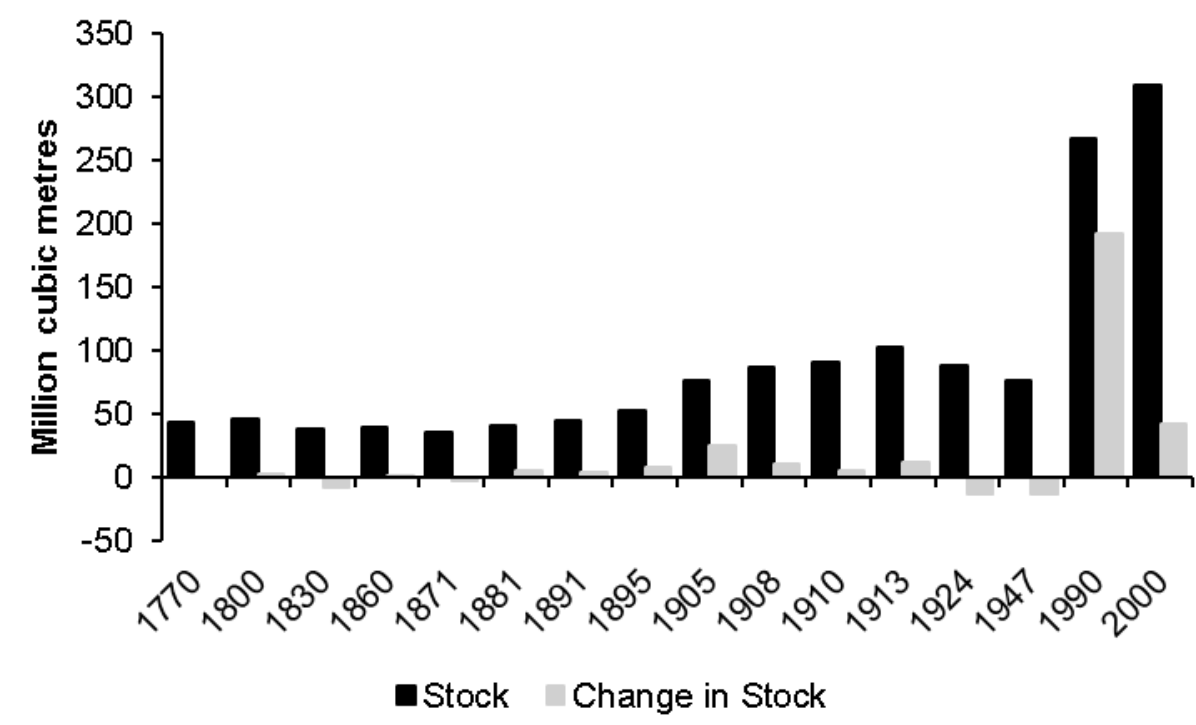


Figure 4: Value of British timber stocks, 1770-2000.

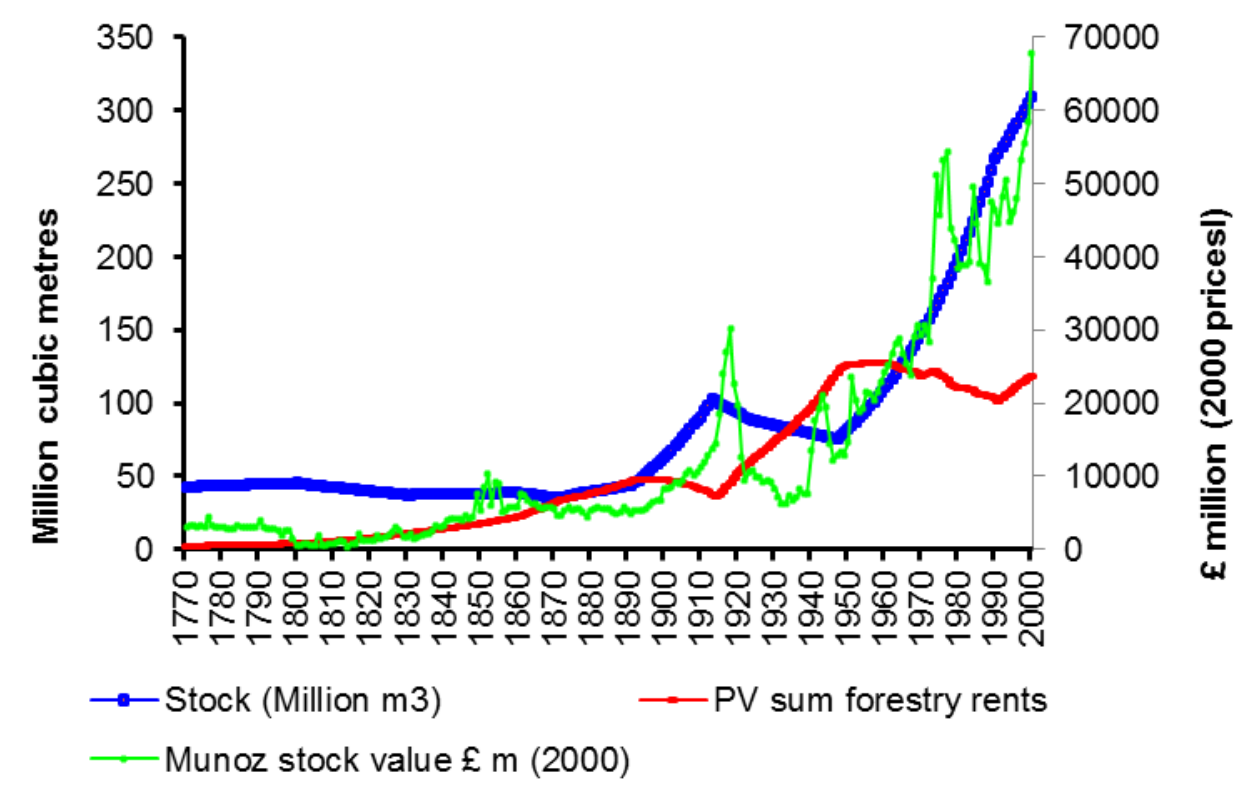

\subsubsection{Coal}

Coal reserves are subject to a distinction between what is technologically feasible and what is economically viable to extract. As technology progresses, deeper and otherwise lessaccessible schemes become more accessible. Technological advance is driven partly by cumulative extraction. However, at any moment in time, the measure of economic reserves will also depend on current prices and extraction costs. Cumulative production over time exerts an upward influence on costs, even as technological progress pushes costs down.

The estimates published in the 1905 Royal Commission give the most detailed assessments of what total reserves were at a point in time, but this is not equivalent to an economic reserve. The data from the 1940 s give us estimates of reserves that are recoverable and proven at that point in time. They exclude much of the reserve estimates made by the 1905 Commission. Table 1 outlines spot estimates of coal reserves from 1866 to 2010. There are large variations in the estimates because of the opinions of geologists and what is considered economic to extract varies with changes in geological knowledge and technology. A coal reserve may 'shrink' for example because on closer investigation geologists discover that it is very complex and fractured and difficult to mine, even though the amount of coal is the same. 
Table 1: Coal reserves and extraction between dates, $1866-2010$

\begin{tabular}{|c|c|c|c|c|c|}
\hline & Known $^{a}$ & Possible $^{b}$ & $\begin{array}{l}\text { Reserve } \\
\text { estimate at } \\
\text { time } t \\
\text { (total) }^{c}\end{array}$ & $\begin{array}{l}\text { Total } \\
\text { Extraction } \\
\text { from } 1750 \\
\text { to date of } \\
\text { reserve } \\
\text { estimate }\end{array}$ & $\begin{array}{l}\text { Total } \\
\text { Extraction at } \\
\text { date as \% of } \\
\text { reserve }\end{array}$ \\
\hline & & & $\begin{array}{l}\text { (million } \\
\text { tonnes) }\end{array}$ & $\begin{array}{l}\text { (million } \\
\text { tonnes) }\end{array}$ & $\%$ \\
\hline c.1866 & & & 85,544 & 3,381 & 3.95 \\
\hline c. 1870 & 97,526 & 100,917 & 198,433 & 3,822 & 1.93 \\
\hline c. 1905 & 106,153 & 40,721 & 146,874 & 9,881 & 6.73 \\
\hline c. 1912 & & & 186,494 & 11,721 & 6.29 \\
\hline c. 1915 & & & 235,000 & 12,528 & 5.33 \\
\hline c. 1940 & 20,500 & 13,376 & 33,877 & 18,265 & 53.92 \\
\hline c. $1945-46$ & & & 54,604 & 19,441 & 35.60 \\
\hline c. 1947 & & & 49,387 & 19,639 & 39.76 \\
\hline 2010 & 262 & 2527 & $2789^{+}$ & 27,302 & \\
\hline $1750-2010$ & & & & 27,302 & \\
\hline
\end{tabular}

Sources: see data appendix. Notes:

a are available reserves known by contemporaries

b Reserves deemed likely to exist by contemporaries

$c$ is the sum of both the known and the possible reserves at the time of the estimate

+ This is an economic reserve. The WEC (2010, pp 38-39) note that 'the amount of coal in place that hosts the proved recoverable reserves is put at 386 million tonnes, implying an average recovery factor of 0.59 . At lower levels of confidence are a 'probable' amount in place of 262 million tonnes, of which 155 is deemed to be recoverable (also with a recovery factor of 0.59), and a 'possible' in situ tonnage of 2527 million tonnes, of which $1396(55 \%)$ is classed as recoverable. A further amount of 1636 million tonnes is reported by the Member Committee as representing potential additional recovery from known resources. The UK's known resources of coal are dwarfed by its undiscovered resources, with nearly 185 billion tonnes estimated to be in place, of which about 41 billion is deemed to be recoverable.'

In our calculations presented in Figure 5, we have chosen the 1905 reserve estimates as a benchmark, as these provide the fullest detail. Furthermore, as the issue is the amount of workable reserves, those reserves deemed technologically workable in 1905 we assume would be workable in the future, even if uneconomic now. The known reserves from the 
1905 coal commission (B.P.P. 1905) are used as a benchmark to obtain estimates of British coal reserves over the period $1750-2000$ by adding annual coal extracted pre-1905 to this benchmark and subtracting annual extraction post-1905. Figure 6 shows the value of coal reserves using both the approaches of the World Bank and Muñoz et al (2012). These different methods of valuing natural capital yield massively different results, as the WB method is just a lagged curve of the value of the extracted coal, while changes in the values using the Munoz method are driven by changes in coal prices and wages as the actual stock doesn't change that much. Thus our WB measure increases steadily as both prices and extraction increases and peaks in 1939, thereafter declining; whereas our Munoz measure of stock value is more volatile and fluctuates according to the prevailing price levels.

Figure 5: Coal stock and annual change in stock (million tonnes) 1750-2008

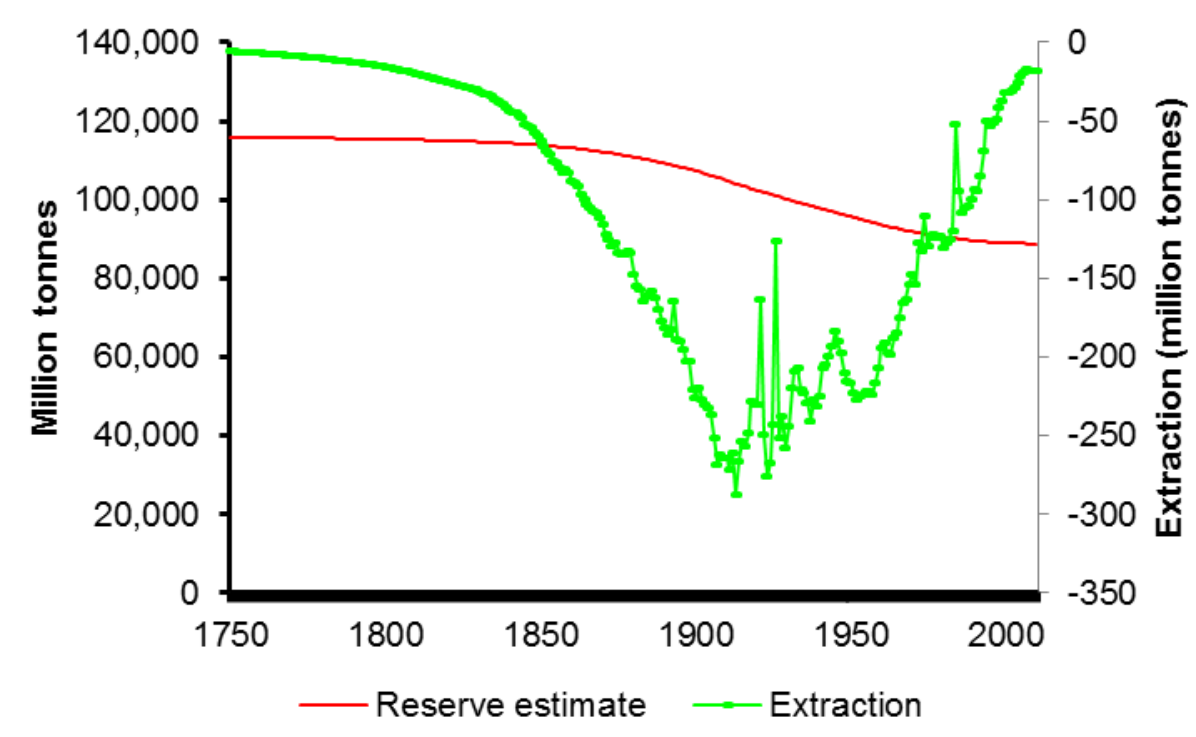


Figure 6: Value of coal reserve in Britain, 1770-2000.



\subsubsection{Iron Ore}

The benchmark estimate used to estimate an annual iron ore reserve was the 3870 million ton estimate from 1920 (Hatch, 1920). Previous iron ore extraction was added to this reserve and subsequent extraction subtracted from the figure, although no adjustments are made for variations in ore quality. Prior to 1850 the amount of ore extracted was relatively small and made very little difference to the reserve, although the accessible reserve in 1750 was much smaller because of technological limitations. Figures 7 and 8 show the resultant physical and economic accounts, according to our two measures of resource wealth. 
Figure 7: Iron ore reserve and change in reserve, 1760-2000

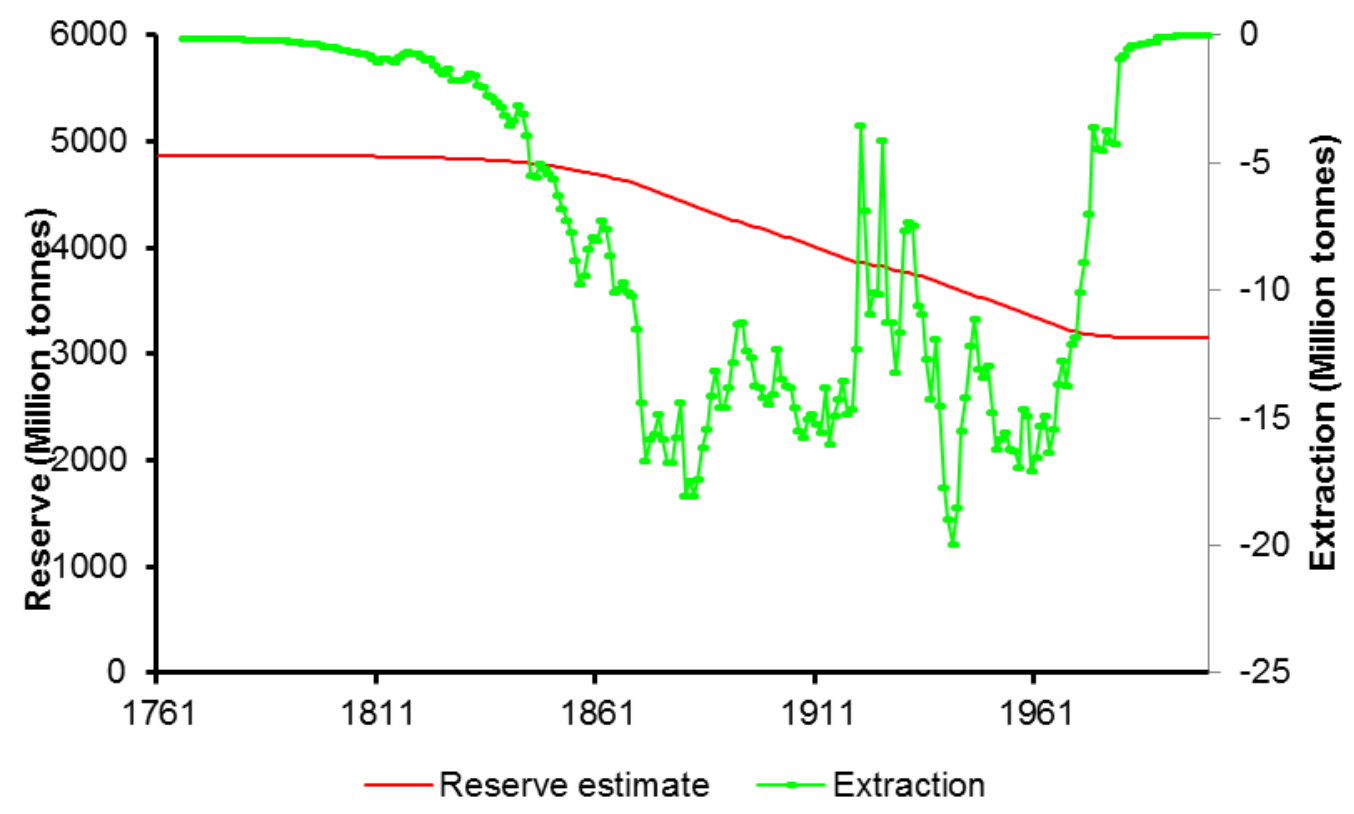

Figure 8: Value of Iron ore reserve, 1801-2000

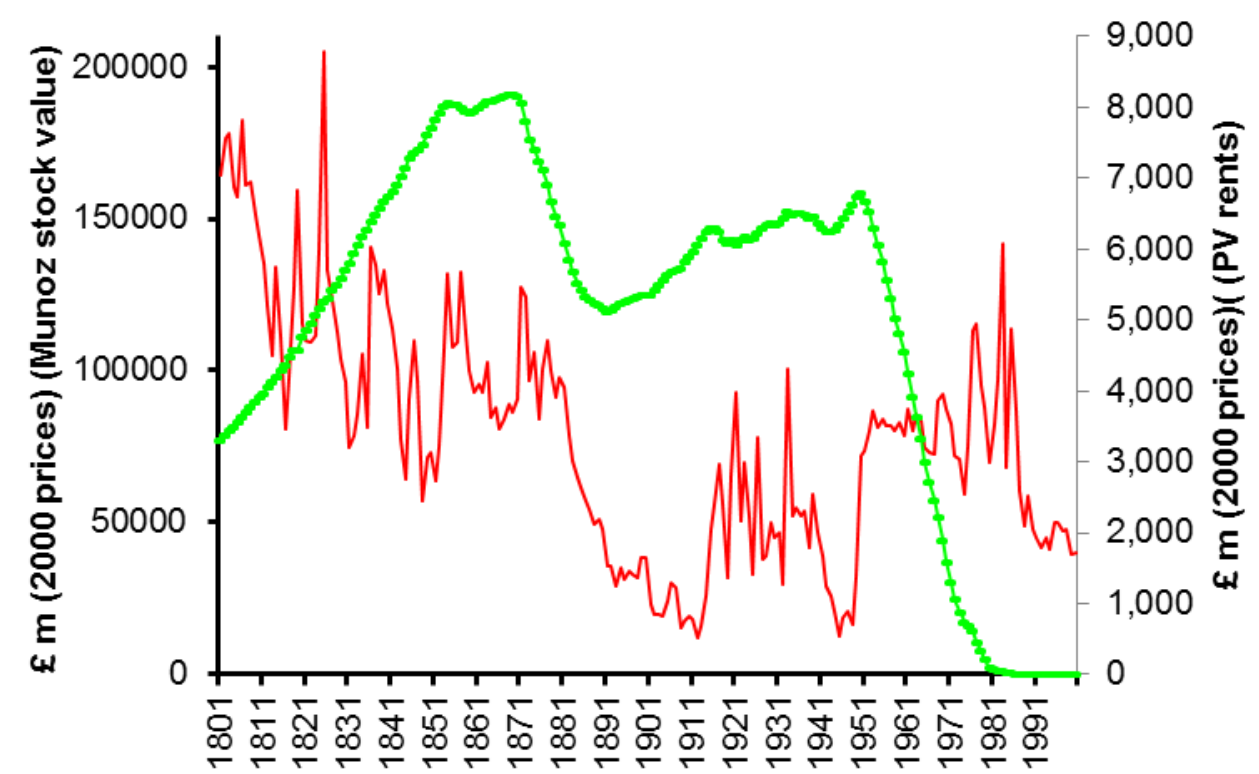

-Munoz stock value $£ \quad-P V$ sum of rents

\subsubsection{Other Minerals}

UK mineral statistics also record the output of non-ferrous minerals such as copper, lead, tin and zinc over the period 1855 to 2000 and we have incorporated these minerals into our wealth accounts. Data on tin, copper, lead and zinc extraction are from Mitchell (1988) and UK mineral statistics and mineral yearbook. Figure 9 illustrates annual extraction of lead, 
copper, tin and zinc. The extracted rental value of these minerals was low; collectively they reached around $0.2 \%$ of GDP in 1850 but this dwindled to around $0.02 \%$ by the 1920 s.

Figure 9: Lead, copper, tin and zinc extraction and reserve value 1855-2000

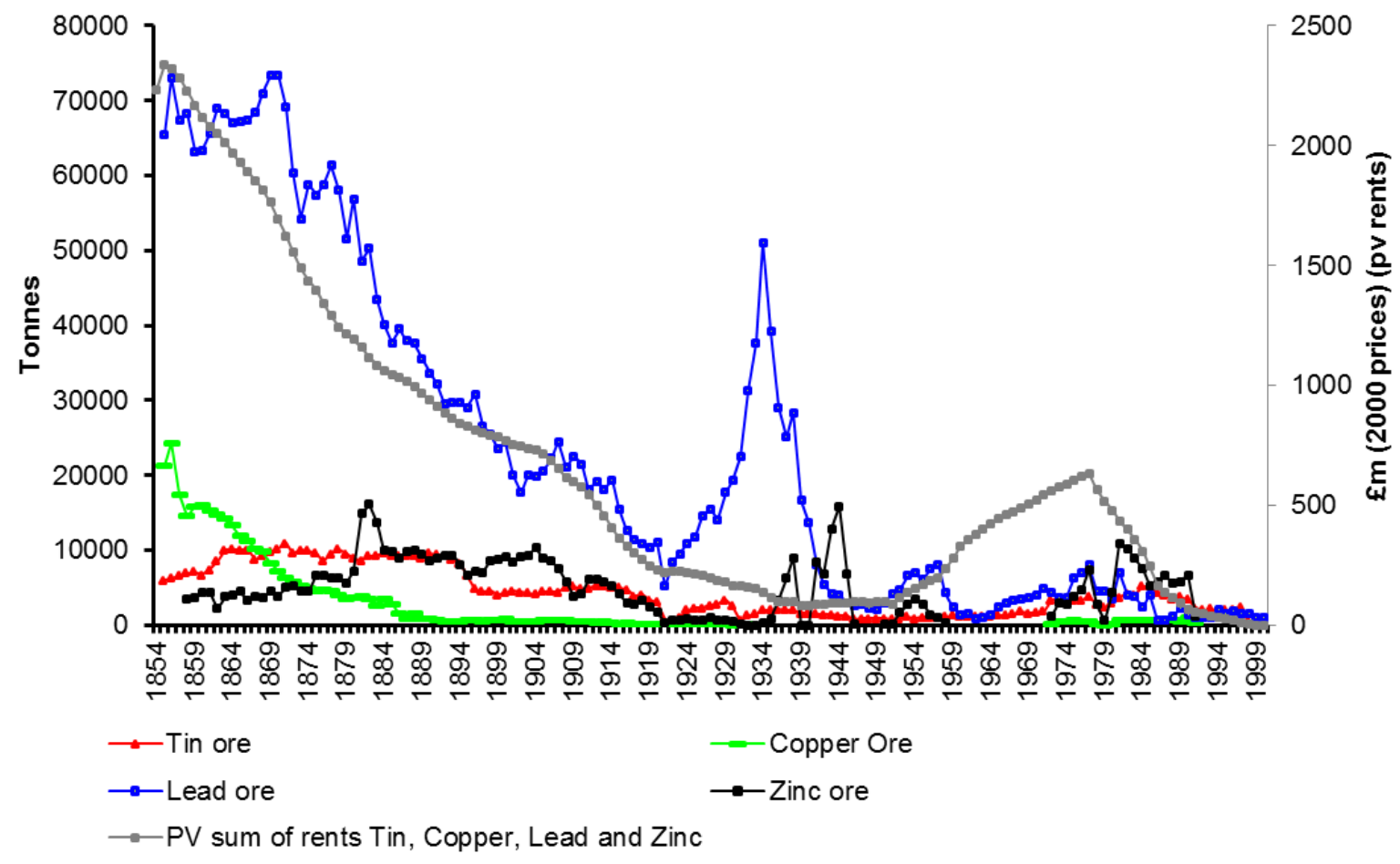

\subsubsection{Oil and Gas}

Oil and gas extraction were negligible before 1920 but became important with extraction from the North Sea, see Figure 10. In 1975 as serious production commenced, DUKES (1975) reports that there were 1,060 million tons proven reserves of oil, 1,205 million tons of probable reserves, 835 million tons of oil possible reserves, giving a total of 3,100 million tons. Reserves of gas were estimated at 44.4 trillion cubic feet in 1975. More recent estimates of oil and gas reserves show a decline. In December 2012 it was estimated that proven oil reserves were 405 million tonnes, probable reserves 405 million tonnes, possible reserves 253 and the maximum reserves 1064 million tonnes. For gas the corresponding figures were 244 billion cubic metres proven, 217 billion cubic metres probable, 238 billion cubic metres possible and 699 billion cubic metres as a maximum (DECC 2013). Figure 10 shows imports and domestic oil production since 1920. 
Figure 10: Imports and domestic extraction of oil (million tonnes), 1920-2000



Figure 11: Value of oil reserve, 1920-2000.



Figure 11 outlines the different methods of valuing oil, and illustrates the conflicts between the two valuation methods. The Munoz stock value peaks just after extraction of North Sea oil commences but decreases as the stock of oil declines, whereas the present value of oil rents increases because oil prices are increasing. The latter implies that even though there is less physically of the resource in 2000 than in 1920, the rise in real prices indicates that the value of the remaining stock is greater than at the start of extraction. The Munoz method 
underestimates the value of the existing stock as it uses current prices to value the stock, rather than looking forward to future values.

\subsubsection{Agricultural Land}

Agricultural land is another component of a nation's natural capital. We have calculated the value of British agricultural land using two alternative methods, multiplying the total area of agricultural land in any year with either the net present value of a stream of future agricultural rents, using the average sales price of agricultural land (note that applying the Munoz method makes no sense for this asset). The area of land in agricultural use changes only modestly since 1760 , whereas there have been long cycles in values per hectare, partly reflecting the fall and rise of agricultural protection, see Figure 12. The net present value (NPV) of agricultural land is estimated as the discounted value of agricultural rents looking 25 years forwards. As the agricultural land in use is rather stable the total value of agricultural land in Britain shown in Figure 13 is driven by the fluctuation in rents or sales values, rather than changes in area.

Figure 12, NPV of agricultural land per hectare in England \& Wales, and Scotland 1770-2010, $f$ /ha (2000 price level).




Figure 13, Value of agricultural land in England \& Wales, and Britain 1770-2010, $f$ /ha (2000 price level).



Estimation of the value of agricultural land based on sale value per hectare provides consistently higher estimates of the value of agricultural land. We speculate the reason for this to be that sale values pick up other reasons for owning agricultural land besides purely agricultural returns, including the value of land in alternative uses (eg housing). We conclude that a calculation based on net present value of agricultural land provide a better estimate of the value of land for pure agricultural uses.

\subsection{Human Capital}

The value of the stock of human capital is estimated using the discounted sum of life time earnings. We follow, with some modifications, the methodology of Jorgenson and Fraumeni (1989) and Le, Gibson and Oxley (2006), and calculate a discounted sum of total annual income from employment discounted over the weighted average years left in the work life of the population in working age using the following formula: 
$H_{t}=W_{t}+W_{t+1} r^{2}+W_{t+2} r^{3}+\cdots+W_{t+n} r^{n}$

$H_{t}=$ Human capital in point $\mathrm{t}$

$W=$ the total annual income from employment

$r=1-$ discount rate

$n=$ the average years left in the work life of the population in working age weighted by the wage share of males and females

See the data appendix for sources and Kunnas et al (2013) for a more detailed explanation of the calculation.

Figure 14 The Value of the UK human capital stock, 1760-2000

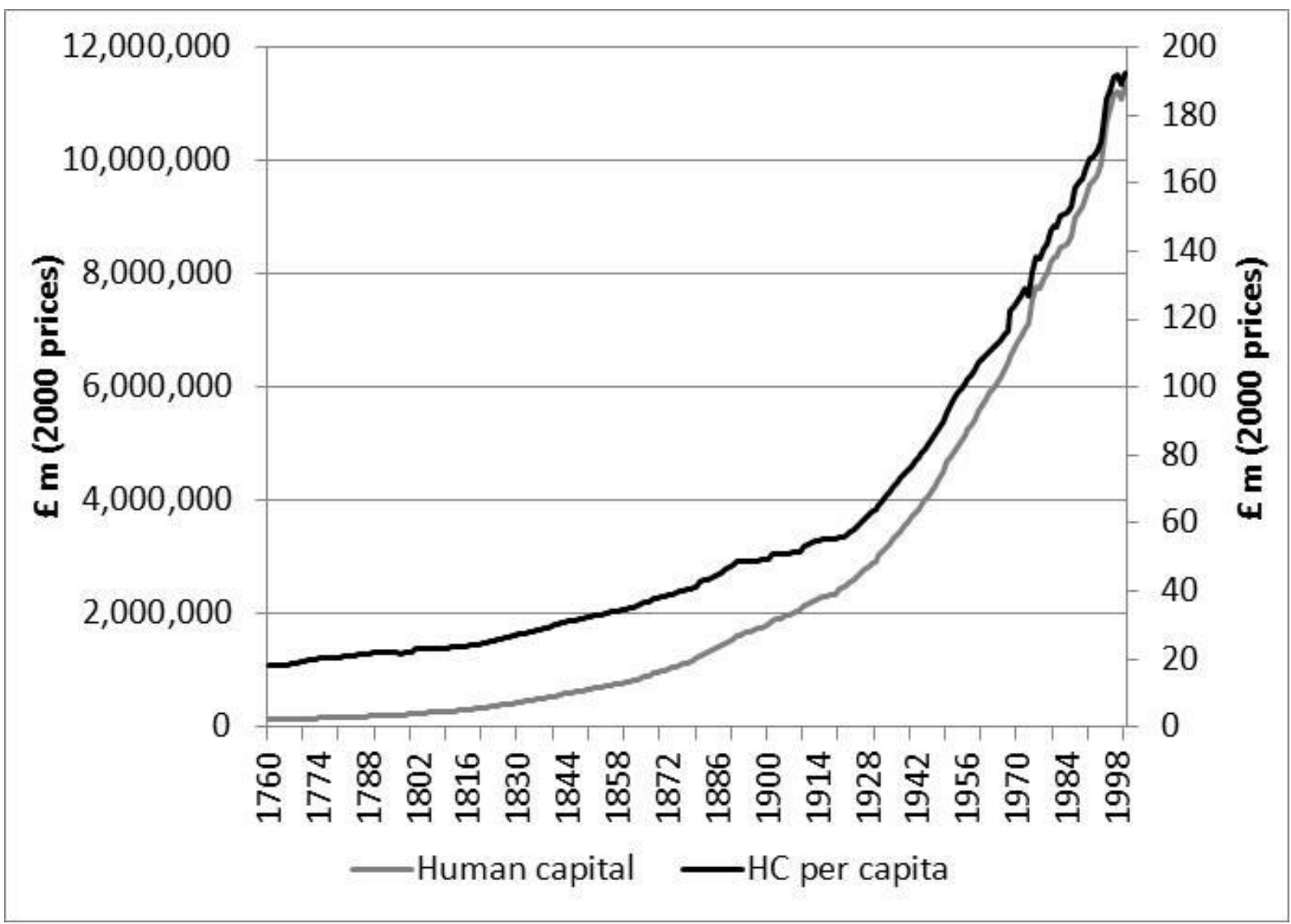

The changing remaining time in workforce had only a small influence on human capital, as longer life expectancies were counteracted by an aging workforce and earlier retirement. As real wages remained almost constant in the late $18^{\text {th }}$ and early $19^{\text {th }}$ centuries, the change in the workforce was initially the main driver of changes in human capital. Increases in the workforce remained the major driver of growth in human capital, even after real wages began to grow after the first decade of the 
$19^{\text {th }}$ century, as the workforce grew by twice the rate of wages up to the mid $19^{\text {th }}$ century, and one third faster from the second half to the First World War. The period after the world wars witnessed fast growth in real wages, while the growth in the workforce stagnated until after 1983, when the size of the workforce reached its lowest point since the end the Second World War.

\subsection{Bringing together the capital estimates}

Having measured reproducible capital, and elements of natural and human capital stocks, we can now estimate "intangible wealth" as the difference between total wealth (Figure 1) and the measured components. In the case of natural capital, the variant based upon the NPV of rents is adopted for the reasons outlined above. The results in Figure 15 show human capital was the major form of capital over the whole period, and accounts for around $60 \%$ of wealth both in 1770 and 2000. Agricultural land was the major element of natural capital until 1893 when it was surpassed by coal. In 1770 from $14 \%$ of total wealth was natural capital, but only $1 \%$ was minerals. The contribution of natural capital to wealth diminished over the next 200 years, but increased after 1970 with the exploitation of North Sea fossil fuel reserves. In 1970 oil and gas represented more than seventy percent of all natural capital, with an increasing share ever since (driven by a long-term upward trend in real prices into the future). The share of produced capital in wealth was relatively stable, but increased to over $10 \%$ in the twentieth century. Residual or intangible wealth peaked at around $30 \%$ in 1870 , but its share was typically lower in the twentieth century.

\section{Figure 15: The composition of wealth}




To compare these findings to others using the same approach, we consider estimates for the UK in 2000, contained in World Bank (2006) - no earlier estimates are available to enable a similar comparison. Table 2 shows the results. It should be noted that the World Bank measure of intangible capital includes human capital, while we have calculated it separately. Hamilton and Liu (this volume) also report UK wealth decompositions for 2005, distinguishing the share of human capital at $61 \%$.

Table 2: The composition of UK comprehensive wealth per capita in 2000 US \$: comparison of this study with World Bank estimate.

\begin{tabular}{|c|c|c|c|c|}
\hline & Net reproducible capital & Natural capital & Intangible capital & Total Wealth \\
\hline World Bank estimates & 55,239 & 7,167 & 346,347 & 408,753 \\
\hline $\begin{array}{c}\text { This study: natural } \\
\text { capital as PV rents }\end{array}$ & 59,485 & 39,078 & 425,866 & 524,429 \\
\hline $\begin{array}{c}\text { This study: Muñoz } \\
\text { natural capital values }\end{array}$ & 59,485 & 29,142 & 292,115 & 524,429 \\
\hline & $\%$ & $\%$ & $\%$ & $\%$ \\
\hline World Bank estimates & 14 & 2 & 85 & 100 \\
\hline $\begin{array}{c}\text { This study: natural } \\
\text { capital as PV rents }\end{array}$ & 13.78 & 9.05 & 77.17 & 100 \\
\hline $\begin{array}{c}\text { This study: Muñoz } \\
\text { natural capital values }\end{array}$ & 13.78 & 6.75 & 79.47 & 100 \\
\hline
\end{tabular}

Notes: Intangible capital includes human capital. The World Bank estimates for the UK include Northern Ireland. Their lower value of total wealth may also reflect their use of a 1.5\%/year discount rate.

\section{British Genuine Savings, 1760-2000.}

This section reports estimates of Genuine Savings (GS) measured constructed directly from investment data. That is, we obtain figures for the year-on-year change in each element of the total capital stock, and then aggregate these together for any year (see Greasley et al, 2013, for more details). Later on in the paper we compare this "bottom-up" approach with a "top-down" approach based on changes in estimated total wealth. Six series of increasinglycomprehensive measures of investment were constructed:

1. NFCF: annual changes in produced net domestic fixed assets

2. NETPINV: annual changes in net produced capital and net overseas assets

3. GREENINV: NETPINV plus changes in elements of the stock of natural capital

4. GS: GREENINV plus public education investment

5. GSTFP: GS plus the value of changes in exogenous technological progress, as measured by changes in total factor productivity 


\section{GSTFPW: GSTFP less wealth dilution}

We now report on findings for each of these.

\subsection{Genuine Savings in the Industrial Revolution, 1760-1850.}

The investment-based estimates of GS are of particular interest over the period of the First Industrial Revolution. Economic historians have long debated the importance of a rise in the savings (or investment) ratio during the Industrial Revolution. Rostow (1960) argued a necessary condition for sustained growth was a rise in the net investment to national income ratio from around $5 \%$ to $10 \%$, for output to outstrip population growth when capital productivity was low. He tentatively dated the period of 'take-off' for Great Britain as 17831802. Subsequent work, notably Feinstein (1978) denied a sharp rise in the investment ratio, instead arguing the gross domestic investment ratio had reached $12 \%$ by the 1780 s and changed little over the next 50 years. Deane and Cole (1969) and Crafts (1985) are more sympathetic to the idea that the investment ratio rose, but they suggest this happened over a more extended period. One curiosity of these studies is their focus on gross investment whereas Rostow (1960) posits net investment as the relevant measure for sustained growth.

Our measure of GS incorporates a wider definition of net investment than used by the above authors. Most importantly, GS broadens the concept of net investment to include natural resource depletion and investment in human capital. For the period 1761-1860, the estimated GS essentially reflects the extent mineral resource depletion was offset by investments in produced capital. Net domestic fixed investment (NFCF) averaged $1.1 \%$ of GDP in the 1770 s and rose sharply to $4.3 \%$ of GDP during the 1830 s and peaks at $5.3 \%$ during the 'railway age' of the 1840s. The results of Table 3 show GS was negative 1760-80, as the extraction of coal and iron ore rents more than offset NFCF. Extracted rents, relative to GDP rose further in the first half of the nineteenth century, but GS was positive, and exceeded $2 \%$ of GDP during the manufacturing and railway investment expansions of the 1830 s and 1840 s. When railway investment fell in the 1850 s so did GS, although it remained positive. 
Table 3: Mean Genuine Savings rates (\% GDP) 1761-1860 (decade averages)

\begin{tabular}{l|lllll}
\hline & NFCF & Education & Forestry & Minerals & GS \\
& & Investment & \multicolumn{3}{c}{ Extraction } \\
\hline $\mathbf{1 7 6 1 - 1 7 7 0}$ & 0.52 & & & -1.10 & -0.58 \\
$1771-1780$ & 1.12 & & 0.05 & -1.20 & -0.04 \\
$\mathbf{1 7 8 1 - 1 7 9 0}$ & 1.38 & & 0.04 & -0.80 & 0.62 \\
$\mathbf{1 7 9 1 - 1 8 0 0}$ & 1.79 & & 0.03 & -0.65 & 1.17 \\
$\mathbf{1 8 0 1 - 1 8 1 0}$ & 2.22 & & -0.02 & -1.23 & 0.97 \\
$\mathbf{1 8 1 1 - 1 8 2 0}$ & 2.51 & & -0.03 & -1.35 & 1.13 \\
$\mathbf{1 8 2 1 - 1 8 3 0}$ & 3.33 & & -0.05 & -1.69 & 1.60 \\
$1831-1840$ & 4.27 & 0.01 & 0.01 & -1.35 & 2.93 \\
$1841-1850$ & 5.31 & 0.02 & 0.01 & -1.75 & 3.60 \\
$1851-1860$ & 3.95 & 0.08 & 0.02 & -2.47 & 1.58 \\
\hline
\end{tabular}

Sources: see Data Appendix

Within a GS framework the case for limiting produced investment to fixed capital formation and domestic investment appears dubious. Inventories and work in progress (sometimes defined as circulating capital) were important elements of capital formation during the Industrial Revolution, and circulating capital increased in every decade 1761-1860. Countries can also hold wealth in the form of investments in other countries. Fixed investment grew more quickly than circulating, which largely explain why, given overseas investment was modest before the 1850s, the NETPINV ratio, see Table 4, rose less quickly than the NFCF ratio. Nevertheless, once circulating capital is included, NETPINV offset the effects of minerals extraction in the 1760 s and 1770 s to give a positive GS for these decades. 
Table 4. Mean Genuine Savings rates (\% GDP) 1761-1860 (decade averages)

\begin{tabular}{l|lllll}
\hline & NETPINV & $\begin{array}{l}\text { Education } \\
\text { Investment }\end{array}$ & Forestry & $\begin{array}{l}\text { Minerals } \\
\text { Extraction }\end{array}$ & GS \\
\hline $1761-1770$ & 1.91 & & -1.10 & 0.82 \\
$1771-1780$ & 3.05 & 0.05 & -1.20 & 1.90 \\
$1781-1790$ & 3.44 & 0.04 & -0.80 & 2.69 \\
$1791-1800$ & 4.13 & 0.03 & -0.65 & 3.50 \\
$1801-1810$ & 1.97 & & -0.02 & -1.23 & 0.72 \\
$1811-1820$ & 5.89 & & -0.03 & -1.35 & 4.52 \\
$1821-1830$ & 7.31 & & -0.05 & -1.69 & 5.57 \\
$1831-1840$ & 5.66 & 0.01 & 0.01 & -1.35 & 4.32 \\
$1841-1850$ & 7.62 & 0.02 & 0.01 & -1.75 & 5.91 \\
$1851-1860$ & 7.77 & 0.08 & 0.02 & -2.47 & 5.40 \\
\hline
\end{tabular}

Sources: see Data Appendix

Other features of the GS estimates of Table 4 are worth highlighting. The GS ratio falls sharply 1801-10, though remains positive. The fall probably reflects the effects of the Napoleonic Wars. While NFCF rose, the increase in circulating capital in the first decade of the new century was lower than in the 1790s. Further, net overseas investment was negative 1801-10. Net overseas investment was relatively modest in the first half of the nineteenth century. In the 1840s it was less than one quarter the value of net domestic investment. Net overseas investment surged in the 1850s and amounted to around twothirds the value of net domestic investment in that decade. The sharp fall in the GS ratio shown in Table 3 for the 1850s is not mirrored in the results of Table 4, reflecting the heightened importance of overseas investment to the British economy in the 1850s. By the 1850s, natural resource depletion in the UK was being offset by net overseas investment, a feature that would persist until the First World War. 


\subsection{Genuine Savings since 1860}

NETPINV relative to GDP nearly doubled 1860-1914 compared to the average of the previous century, see Table 5 . This was largely due to higher net overseas investment which underpinned rise in the GS/GDP ratio in the period 1850-1910 to a peak of around $9 \%$. Produced investment fell dramatically during the world wars, and the NETPINV ratio was low 1914-45. The recovery of produced investment after 1945 was largely due to a rise in NFCF. GS typically mirrors the contours of produced investment. However, while GS shows lower values than NETPINV to 1914, reflecting the depletion of minerals, GS was above NETPINV in the twentieth century, reflecting the rise in education investment. The increasingly-comprehensive measures NETPINV, GREENINV, GS, and GSTFP are illustrated as Figures 17 and 18. The real values of British GS per capita and of GS as a percentage of GDP were generally positive 1860-2000, but negative during the First and Second World Wars.

Table 5: Net Produced Investment (NETPINV) and GS as \% GDP 1760-2000

\begin{tabular}{l|cccccc}
\hline & NFCF & Inventories & Net Domestic & Net Overseas & NETPINV & GS \\
\hline $\mathbf{1 7 6 0 - 1 8 6 0}$ & 2.64 & 1.08 & 3.72 & 1.15 & 4.87 & 3.56 \\
$\mathbf{1 8 6 0 - 1 9 1 4}$ & 3.73 & 0.74 & 4.47 & 4.70 & 9.17 & 7.68 \\
$\mathbf{1 9 1 8 - 1 9 3 8}$ & 2.39 & 0.01 & 2.40 & 0.82 & 3.22 & 3.26 \\
$\mathbf{1 9 4 6 - 2 0 0 0}$ & 7.06 & 0.60 & 7.66 & -0.22 & 7.44 & 9.54 \\
$\mathbf{1 9 1 4 - 1 9 1 8}$ & 0.07 & -0.62 & -0.55 & 0.21 & -0.34 & -2.50 \\
$\mathbf{1 9 3 9 - 1 9 4 5}$ & -0.91 & -0.20 & -0.71 & -7.56 & -8.27 & -8.60 \\
$1946-1968$ & 7.42 & 0.96 & 8.38 & 0.01 & 8.39 & 10.43 \\
\hline
\end{tabular}

Sources: see Data Appendix. 
Figure 16: Alternative Investment measures as \% GDP

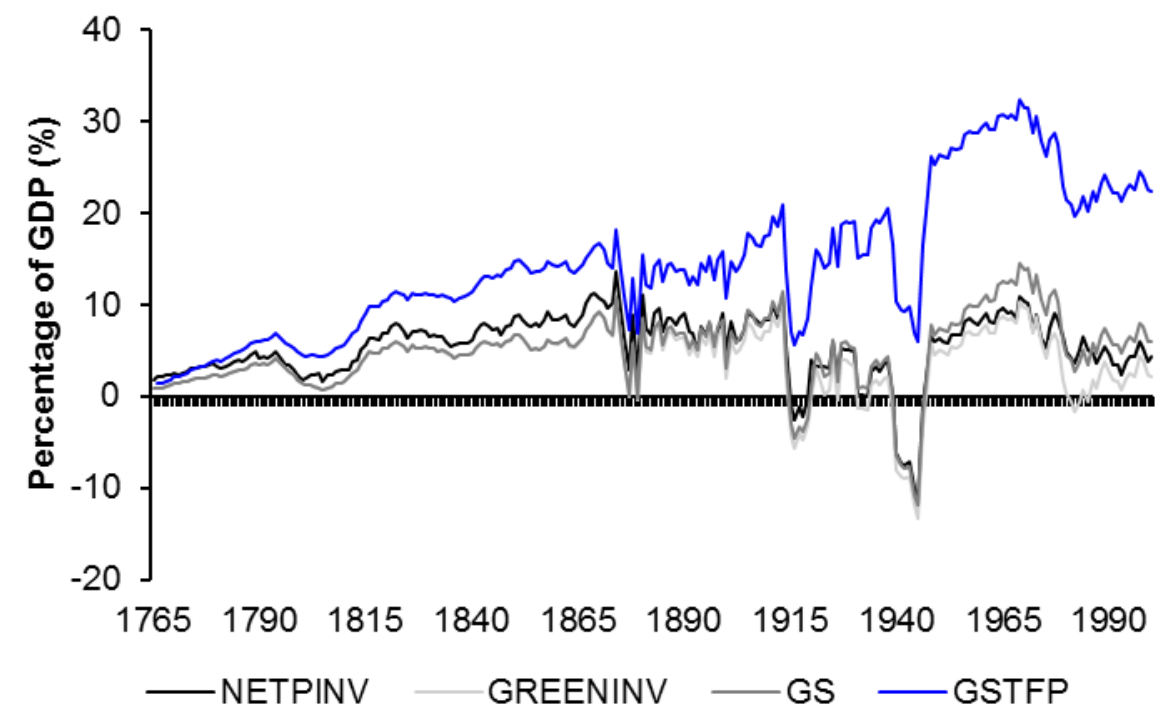

Note: The TFP measure is based on a 20 year horizon and $2.5 \% /$ year discount rate.

Figure 17: Alternative Investment measures per capita

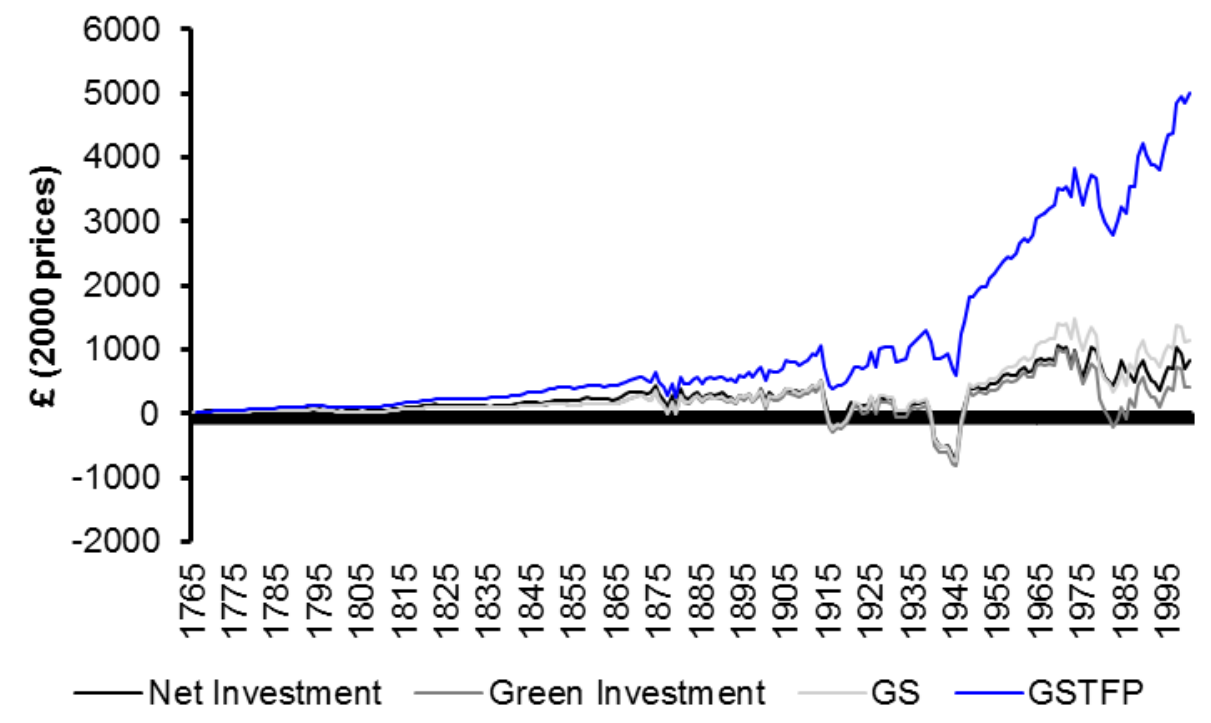

\subsection{Allowing for technological progress in the measurement of Genuine Savings.}

Weitzman (1997) and Pemberton and Ulph (2011) advocate the inclusion of exogenous techological progress in assessments of (changes in) the capital stocks of a country. Treating time as an uncontrolled capital stock means productivity's contribution to the change in wealth in any year should be added to GS. The case for including exogenous technological progress within a more comprehensive investment measure appears strong in light of the widespread evidence that residual productivity plays a central role in the consumption growth of OECD countries. Trend TFP estimates shown in Figure 19 underpin our valuation 
of exogenous technological progress. Our approach to gauging how TFP contributes to changes in the value of wealth follows Pezzey et al (2006) and calculates the present value of future changes in TFP over a 20 years horizon using a 2.5\%/year discount rate. According to this methodology, the value of discounted technological progress, relative to GDP increases over time. For $1765-1799$ the average is $2.21 \%, 1800-1899$ it is $7.85 \%, 1900-1949$ it is $15.34 \%$, and $1950-1999$ it is $21.21 \%^{6}$. GSTFP averaged $29 \%$ of GDP $1960-2000$.

Figure 18 Trend TFP growth rate, 1766-2020 (\%)



Notes: for sources and methods see Data Appendix

\section{Investment and changes in Wealth: some puzzles}

In this section, we review 4 puzzles in wealth accounting and measuring GS, which have all been hinted at above. First, GS should be equal to changes in total wealth. We have measured GS in section 3 using annual figures for net investment/depletion of each element of total capital (a "bottom up" approach). Wealth can also be measured in a bottom-up way for each part of total capital which can be measured, and this is what we reported in section 2. However, total wealth and intangible (residual) wealth is calculated using a top-down approach, which starts from the present value of future (public + private) consumption flows. As Figure 20 shows, the estimates of total wealth changes differ from those of investment-based GS. GSTFP conform reasonably well with changes in total wealth 1900-75, but for earlier and later years there are marked disparities. Nor do the key drivers of the

\footnotetext{
${ }^{6}$ It is interesting to compare the size of this adjustment with Weitzman (1997): he found that a technological change premium could be as high as $40 \%$ of NNP.
} 
change in wealth, particularly human capital formation, match the dominant investment variables, namely produced investment and the value of technology. The discrepancies in the components of wealth and investment partly reflect measurement conventions, which, for example, ascribe technology-productivity gains to labour in the wealth accounts, but where, in contrast, the value of TFP encapsulates technology in the investment accounts. Similarly, the extraction of minerals equates to disinvestment in the investment accounts, while the value of natural resource rents can increase, alongside extraction, in the wealth accounts. Indeed, at the component level, only produced investment is defined as equivalent to changes in the produced capital stock. Top down estimates of wealth rest on the quality of the consumption data, but also on a range of assumptions, including of the discount rate (Hamilton and Liu, this issue).

One possibility is that the ratio of income, and thus of consumption, to wealth was lower before 1900, and that the top down approach overstates changes in wealth over these years. The intuition here is that the returns to wealth were smaller in the lower productivity pre-1900 economy. Over the entire period 1760-1986, the ratio of GSTFP to change in total wealth was $49 \%$. However, for the sub-period 1948-1974 the ratio was $85 \%$ but this declined to an average of $60 \%$ in the sub-period 1975-1986. The reason for this drop is mainly due to faster growth in consumption in the period $1975-2000,2.38 \%$ versus $1.82 \%$ for GSTFP. This is particularly evident in the period 1975-1986, the least discounted years in the wealth calculation, where consumption grew at $1.80 \%$ whilst GSTFP grew at a rate of $0.57 \%$ per annum. From 1987 onwards wealth is estimated using a different methodology which explains later divergence. Post-1987 wealth data are derived from the present value of consumption from a single year rather than the smoothed net present value of 25 years of consumption, thus explaining the fluctuations. 


\section{Figure 19: Change in total wealth, GS and GSTFP per capita, 1760-1986}

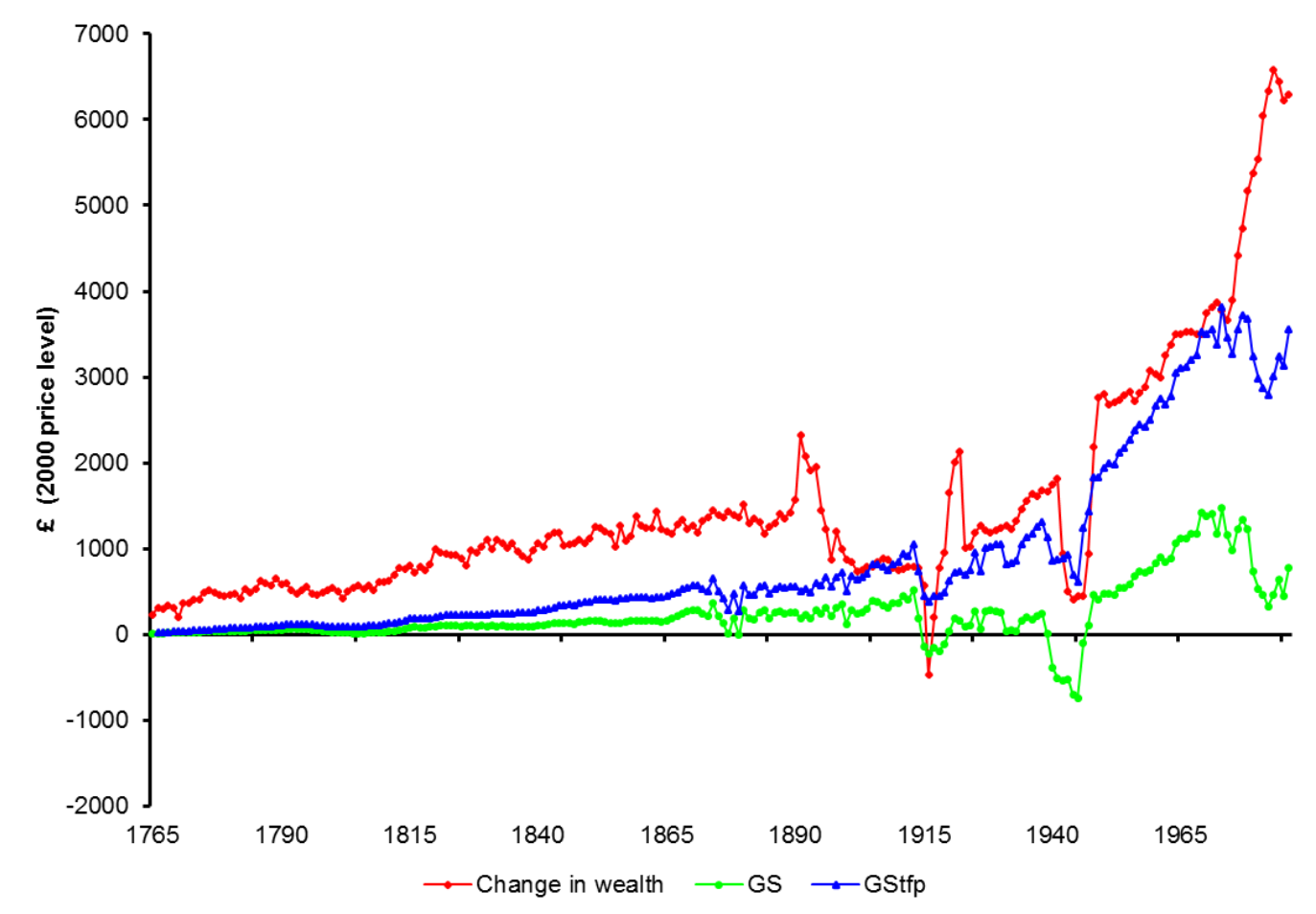

The investment accounts only partially measure some forms of natural and most especially of human capital. Investment in education would ideally incorporate the value of private as well public education. Workplace training, including apprenticeships and mentoring, is also missing from our estimates of education investment. Accordingly, the contribution of human capital formation in the investment-based estimate of GS is small, at least before 1945. In contrast, the life-time earnings approach to gauging the value of the human capital stock shows that human capital dominates total wealth. The difference essentially reflects the choice of accounting convention. In the investment-side accounts, gains in labour productivity connected to human capital formation reside in the measure of TFP. Without augmenting GS with a value of TFP, the GS/GDP ratio averages around 9\% after 1945, whereas GSTFP/GDP averages 29\%. Around two-thirds of GSTFP since 1945 is associated with residual productivity, which will partly reflect unmeasured human capital formation, but also exogenous technology and intangible, social capital. An important issue is thus whether top-down measures of changes in total wealth or bottom up investment measures augmented with TFP provide the more robust indicator of GS and thus sustainability. On balance, our view is that bottom up investment-based measures augmented with TFP are likely to better represent British GS in the long run.

A second puzzle relates to how to value changes in non-renewable resources as one component of natural capital. As Section 2 shows, using the World bank discounted future 
rents approach gives a very different picture, especially for oil and gas and for coal. Which measure to prefer depends on whether we think that current abundance is a more appropriate measure of a resource than likely future price changes. Related to this is the problem that the state of technology in any year partly dictates what we consider to be part of this natural capital. A national accountant in 1800 would not have counted North Sea oil reserves as part of the UK's national wealth, since there was no technology available to exploit it. Yet the oil was still there. A third puzzle refers to the measurement of wealth through the use of discounted present values of future returns, since in both theory and numerical calculations of GS and comprehensive wealth we often assume the relevant discount rate to be constant over time, and that this rate of return applies equally to all sectors of the economy. Yet the historical record shows us that neither of these simplifications describes reality (eg for the UK over the period considered in this paper).

Finally, we need to be able to handle changes in population and think about the effects of pollution on measures of wealth and changes in wealth. The next two sections briefly consider these issues for our period.

\section{Including the effects of carbon dioxide emissions in the GS accounts.}

Contemporary estimates of GS often include a value for the costs of $\mathrm{CO}_{2}$ emissions as a depreciation of the stock of natural capital - an erosion of the earth system's ability to absorb greenhouse gases and avoid catastrophic warming (World Bank, 2011). British carbon dioxide emissions over time equate to disinvestment in assimilative capacity. The marginal damage cost of $\mathrm{CO} 2$ is lower in earlier years (eg 1750) since carbon dioxide is a stock pollutant. One carbon unit added to present-day higher stocks will cause more damage than a unit emitted under the lower concentration levels in the past. Following Lindmark and Acar (2013), the unit damage price is discounted by $2 \% /$ year, since the social cost of carbon is time dependent, as more damage occurs in the future. There are large variations in the estimates of the unit costs of climate change from carbon emissions. Tol's (2008) estimate of $\$ 23 / \mathrm{tC}$ in 1995 is from a meta-analysis of 211 estimates of the social cost of carbon. The Stern Review (2007) postulated a range of higher costs in 2000 from $£ 68.2 / \mathrm{tC}$

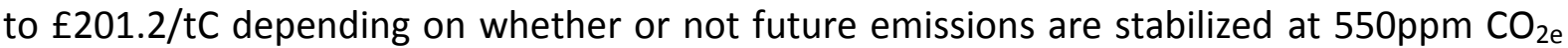
or continue to grow (the lower price was used by Lindmark and Acar, 2013). These three unit damage price estimates, together with historical carbon emissions data based on information inBoden et al. $(1995,2012)$ and Warde $(2007)$ yield the damage costs illustrated in Figure 20, which are then incorporated in the GS estimates in Figure 21. 
Figure 20: Annual costs of carbon dioxide emissions (2000 prices), 1760-2000



Carbon emissions, within the postulated range of unit damage price had very little effect on the sustainability of past British economic development as measured by GS. However, that does not mean emissions of carbon dioxide will have only limited effects on future prosperity. Past emissions have eaten into the cumulative absorption capacity, and can thus be seen as an environmental depletion with potentially lasting consequences. The cumulative costs to 2000 range from $£ 100-480$ billion depending on which unit price we use, with $96 \%$ accrued since 1900 . This represents a big debt to future generations.

Figure 21 British GS with Carbon Costs, 1765-2000



....... GS _ GS with carbon (low) _ GS with Carbon (median) - - - GS with Carbon (high) 


\section{Population change and wealth-dilution.}

Ferreira, Hamilton and Vincent (2008) argue the wealth dilution effects of population growth should be included in GS. Their "wealth dilution effect" is the product of the population growth rate and total wealth per capita, and arises from the sharing of a given amount of capital between more people. So long as the population growth rate is positive, wealth dilution, reduces GS per capita. Average British population growth over the period $1760-2000$ is $0.86 \% / y e a r$. The rate was higher before 1900 , to raise a potentially high barrier to sustainable development as defined by a positive GS. Figure 23 shows the size of the wealth dilution adjustment, which rises strongly to around 1900. The swings in twentieth century wealth dilution partly reflect the fluctuations in wealth and population growth around the world wars. Generally, lower rates of population growth diminish wealth dilution in the twentieth century, although data quality varies across the period making inferences more difficult. For more analysis on the implications of this effect, see Greasley et al (2013). Also, as noted above, the sharp fluctuations post-1987 are statistical artefacts arising from estimating wealth from a single years consumption.

Figure 22: Change in total wealth per capita adjusted for wealth dilution and Wealth dilution from population growth, 1761-2000






\section{Concluding Remarks}

This paper reports one of the first attempts to measure Total Capital or Comprehensive Wealth over the long run. The wealth estimates show that Britain built-up stocks of produced and human capital, as it depleted some stocks of natural capital (principally coal), while other natural capital (land and forests) became relatively less important. Estimates of the value of non-renewable resources as part of natural capital vary substantially according to which approach is used for their measurement. Our Genuine Savings (GS) indicator shows these year-on-year changes in comprehensive wealth. Overall, we find that GS was positive 1760-2000, except during major wars. The chief puzzles arise in the comparisons of changes in total wealth and GS when measured from the investment side. The top down estimates of wealth show higher levels of GS pre-1900 than the investment series, even when the later are augmented with a value of technology. On balance, our view is that the more pessimistic investment-based estimates are the more robust.

Thus, a (hypothetical) Treasury minister in 1780 s London who estimated GS as an indicator of the sustainability of development during the Industrial Revolution should have looked forward to rising well-being over the next 100 years, but, if prudent, the assessment would have reflected upon and been tempered by the uncertainties surrounding faster population growth and warfare. By the 1850s sustainability was more certain. The most important adjustments to Britain's capital stock turn out to have been investments in produced capital and, before 1914, in overseas assets, which more than offset the value of the depletion of non-renewable coal and iron ore stocks. Thereafter, with slower population growth and knowledge advances, including those associated with human capital formation, only the declines in wealth during the two world wars raised serious doubts about British sustainability.

The wealth accounts, by attributing productivity gains to workers, highlight the importance of human capital, which, in our estimates, comprises at least $60 \%$ of wealth in most years. In contrast, the direct measure of investment show lower, albeit faster rising, education investment. Thus, much of the value of investment-estimated GS resides in the value of technology, most especially in the twentieth century. The wealth accounts also include an intangible residual, which in our estimates peaks in importance at around $30 \%$ in the second half of the nineteenth century.

On balance, our view is that the decompositions of wealth changes from the investment side have more value. This interpretation rests partly on the uncertain quality of the aggregate top down wealth estimates, which in turn affects the relative size of the measured elements of total wealth and the intangible residual. Additionally, while measuring human capital by (lifetime) wages has solid theoretical foundations and provides a plausible description, the approach by-passes the question of what drives wages. In part, the answer might be education investment, which can be isolated in the investment accounts, or a range of productivity forces, which again might be better explored via more 
finely grained investment accounts. Accordingly, an empirical analysis of the relationship between GS and future well-being should probably utilize investment-side accounts. 


\section{References}

Arrow, K.J., Dasgupta P., Goulder L., Mumford K. and Oleson K. (2012), Sustainability and the Measurement of Wealth. Environment and Development Economics, 17(3): p. 317-353.

Ashworth, W. (1986), The History of the British Coal Industry, 1946 - 1982: The Nationalized Industry, Vol. 5, Oxford: Clarendon Press.

Barbier, E.B. (2011) Capitalizing on Nature. Cambridge: Cambridge University Press.

Beacham, A. (1946), 'The coalfields of Great Britain', The Economic Journal 56(222), 319-325.

Boden, T. A., Marland, G. Andres, R. J. (1995), 'Estimates of global, regional, and national annual $\mathrm{CO}_{2}$ emissions from fossil-fuel burning, hydraulic cement production, and gas flaring: 1950-1992', ORNL/CDIAC-90, NDP-030/R6.

http://cdiac.ornl.gov/epubs/ndp/ndp030/ndp0301.htm

B.P.P. (1905), 'Royal commission on coal supplies', H.C. [Cd. 2353].

Crafts, N. (1985), British Economic growth during the Industrial Revolution, OUP.

Crafts, N. (1995), Exogenous or Exogenous Growth- The Industrial Revolution Reconsidered, Journal of Economic History, 55, 745-72.

d'Autume, A. \& Schubert, K. (2008), 'Hartwick's rule and maximum paths when the exhaustible resource has an amenity value', Journal of Environmental Economics and Management, v56(3), pages 260-274.

Deane, P and Cole W. (1969), British Economic Growth 1688-1959, $2^{\text {nd }}$ ed, CUP.

DECC (2013), Oil and gas: field data: https://www.gov.uk/oil-and-gas-uk-field-data

DUKES (1975), Digest of UK Energy statistics, Department of Trade and Industry.

Escosura, L. and Roses J. (2010), "Human capital and economic growth in Spain, 1850-2000" Explorations in Economic History, 47 (4), 520-532.

Feinstein, C. H. (1972), National Income, Expenditure and output of the United Kingdom, 1855-1965, Cambridge University Press.

Feinstein, C. H. (1978). 'Capital formation in Great Britain', in Mathias, P. \& Postnan, M. M. (Eds.) The Cambridge Economic History of Europe Capital formation in Great Britain, Cambridge University Press: 28-96.

Feinstein, C. H. Pollard, S., eds (1988), Studies in Capital Formation in the United Kingdom, 17501920, Oxford University Press.

Ferreira, S., Hamilton, K. \& Vincent, J. R., (2008), 'Comprehensive wealth and future consumption: accounting for population growth', The World Bank Economic Review, 22, 233-248.

Greasley D, Hanley N, Kunnas J., McLaughlin E., Oxley L. and Warde P. (2013), "Testing Genuine Savings as a forward-looking indicator of future well-being over the (very) long run" Manuscript, University of Edinburgh, School of History. (under review, Journal of Environmental Economics and Management). 
Hamilton, K., and Clemens, M. (1999), 'Genuine Savings Rates in Developing Countries', World Bank Economic Review 13:2, 33-56.

Hamilton, K., and Withagen, C. (2007), 'Savings and the Path of Utility', Canadian Journal of Economics , 40, pp 703-713.

Hanley, N., Shogren, J. F., White, B. (2006), Environmental Economics in theory and practice. Palgrave Macmillan.

Hartwick, J. M, (1977), 'Intergenerational Equity and the investing of rents from Exhaustible Resources', American Economic Review, 67(5), pages 972-74.

Hatch, F. H. (1920), 'The iron ore supplies of the world', Geological Magazine 57, 504-517.

Jevons, W.S. (1866), The coal question: an inquiry concerning the progress of the nation and the probable exhaustion of our coal-mines, Macmillan and co.

Jorgenson, D. W. and Fraumeni, B. M. (1989), "The Accumulation of Human and Nonhuman Capital", 1948-84. In R. E. Lipsey and H. S. Tice (eds.) The Measurement of Saving, Investment and Wealth.

Kamps, C. (2006), 'New Estimates of Government Net Capital Stocks for 22 OECD countries, 19602001'. IMF Staff Papers. 53(1), 120-150

Kunnas, J., Hanley, N., McLaughlin, E., Greasley, D., Oxley, L. \& Warde, P. (2013), 'Human Capital in Britain, 1760 to 2009', Presentation at Economic History Society, Annual Conference, York 5-7 April. http://www.ehs.org.uk/dotAsset/6db90702-8881-4db3-b4e7-e2b7ca351b51.pdf

Le, T., Gibson, J. \& Oxley, L. (2006), 'A forward-looking measure of the stock of human capital in New Zealand', The Manchester School, 74, 593-609

Lindmark, M. \& Acar, S. (2013), 'Sustainability in the making? A historical estimate of Swedish sustainable and unsustainable development 1850-2000' in Ecological Economics 86, 176-187.

Mitchell, B. R. (1988), British historical statistics, Cambridge University Press.

Muñoz, P., Darkey, E., Oleson, K., and Peason, L. (2012). 'Accounting for the inclusive wealth of nations: empirical evidence'. UNU-IHDP and UNEP. Inclusive Wealth Report 2012: Measuring Progress toward sustainability. Cambridge: Cambridge University Press.

Neumayer E. (2010) Weak Versus Strong Sustainability: exploring the limits of two paradigms. Cheltenham: Edward Elgar.

Officer, L. H., and Williamson, S. H. (2010), 'Measures of worth'.

www.measuringworth.com/worthmeasures.php

Pearce, D.W. and Atkinson, G. (1993), Capital theory and the measurement of sustainable development: an indicator of weak sustainability. Ecological Economics 8: 103-108.

Pemberton M. and Ulph D. (2011), Measuring income and measuring sustainability, Scandinavian Journal of Economics, 103, 25-40.

Pezzey, J. (2004), 'One-sided sustainability tests with amenities, and changes in technology, trade and population', Journal of Environmental Economics and Management, 48, pp 613-631. 
Pezzey, J. C., Hanley, N., Turner, K. \& Tinch, D. (2006), 'Comparing augmented sustainability measures for Scotland: Is there a mismatch?', Ecological Economics, 57, 70-74

Rostow, W. W., (1960), The Stages of Economic Growth, Cambridge University Press.

Stern, N. (2007), The Stern Review on the Economics of Climate Change, Cambridge: Cambridge University Press.

Tol, R. S. J. (2008), 'The Social Cost of Carbon: Trends, Outliers and Catastrophes' in Economics, The open-Access, Open-Assessment E-Journal 2, 1-24.

Warde, P. (2007), Energy consumption in England and Wales, 1560-2000, Consiglio Nazionale delle Ricerche: Instituto di Studi sulle Societa del Mediterraneo.

World Bank (2006), Where is the wealth of nations? Measuring Capital for the 21st century (Washington D.C.).

World Bank (2011), The Changing Wealth of Nations Measuring Sustainable Development in the New Millennium (Washington D.C.).

WEC (World Energy Council) (2010), 'Survey of energy resources 2010', http://www.worldenergy.org/publications/3040.asp

Weitzman, M. (1997), Sustainability and Technical Progress, Scandinavian Journal of Economics, 99, 1-13. 